\title{
Post-Traumatic Intra-Cocoon Mesenteric Tear: A Case Report
}

\author{
Saed Jaber Khalid Dulaijan Moutamn Sadoun \\ Khalid Moghazy Mohsen El-Said \\ Department of Surgery, King Fahd Medical Military Complex, Dhahran, \\ Saudi Arabia
}

\section{Key Words}

Sclerosing peritonitis - Abdominal cocoon $\cdot$ Bowel obstruction

\begin{abstract}
Sclerosing peritonitis, more commonly called abdominal cocoon, is a rare intra-peritoneal disease that is characterized by complete or partial encapsulation of the small intestine by a thick collagenous membrane. This disease mostly presents in the form of small bowel obstruction, however in our case the patient presented with intra-cocoon bleeding following a motor vehicle accident.
\end{abstract}

\section{Introduction}

Sclerosing peritonitis has many different names with no consensus for the ideal syndrome name. It is also called peritonitis fibrosa incapsulata or abdominal cocoon and was originally described in 1907 as a membranous encapsulation of the small intestine [1]. It was then further investigated and a detailed description was made by Foo et al. in 1978 [2]. Most of what has been published are case reports since this disease is rare. According to the literature, this disease presents most commonly with small bowel obstruction in the form of either complete or partial obstruction [3]. We report a rare presentation of this disease in the form of bleeding from the wall itself following a motor vehicle accident.

\section{Case Report}

A 37-year-old male presented to our emergency department as the victim of a road traffic accident with blunt abdominal trauma and generalized abdominal pain. Primary survey was within normal with stable vital signs. Abdominal examination showed a distended abdomen with generalized tenderness. Hemoglobin level on presentation was $13.6 \mathrm{~g} / \mathrm{dl}$. Emergency computed tomography of the abdomen and pelvis was done and revealed small hemoperitoneum and a loculated hematoma within a sac containing the small bowel as shown in figure 1. 
The patient was admitted to the male surgical ward for observation and conservative management. About one hour after admission he started to be drowsy and his blood pressure dropped from $119 / 87 \mathrm{~mm} \mathrm{Hg}$ at admission to $74 / 47 \mathrm{~mm} \mathrm{Hg}$ and he became tachycardic. Abdominal examination showed distended abdomen with generalized tenderness and generalized rebound tenderness. Hemoglobin and hematocrit levels dropped markedly from $13.6 \mathrm{~g} / \mathrm{dl}$ and $42.3 \%$ to $10.5 \mathrm{~g} / \mathrm{dl}$ and $32.1 \%$, respectively.

Emergent exploratory laparotomy was performed. Operative findings were as follows: a large cyst containing the whole small bowel from the duodenojejunal flexure down to the ileocecal junction, with massive hemorrhage into it, along with a small amount of blood around the liver, spleen and pelvis (fig. 2). The cyst was opened up and a large amount of blood clots was evacuated. A deep through and through radial mesenteric tear from the root of the mesentery down to the wall of the ileum was seen with no evidence of bowel ischemia. Bleeding was controlled and the tear was closed. Excision of the cyst along with partial omentectomy was done and homeostasis was maintained. Postoperatively he recovered well, with an uneventful hospital stay. Histopathological examination of the abdominal, omental and mesenteric tissues showed a cystic wall lined by low cuboidal mesothelial cells composed of congested fibrofatty and collagenous tissue.

\section{Discussion}

As previously mentioned, abdominal cocoon is a rare disease described by Foo et al. in 1978 [2]. Subsequently many case reports have described its presentation, pathogenesis, prognosis and radiological manifestations. Most descriptions in the literature showed a high prevalence of small bowel obstruction in these patients who are usually young, middle-aged and living in tropical areas [3]. Other reports described an asymptomatic abdominal mass or an accidental radiological or intra-operative finding. In our report we present a case with intra-cocoon hemorrhage due to mesenteric tear within the cocoon caused by blunt abdominal wall trauma in a motor vehicle accident. The question we asked ourselves was whether such a condition predisposes patients to have easily an injury of the mesentery due to the short mesentery and the presence of the cocoon.

Radiological manifestations are challenging to be concluded as an intra-abdominal cocoon, however Sieck et al. described the presence of cauliflower sign on a contrast small intestine study [4], and Maguire et al. described the delay of passage of contrast to be more common and diagnostic than the cauliflower sign [5]. Wig and Gupta described the presence of a membrane around a cluster of small intestine [6]. Clatworthy et al. described the calcified abdominal cocoon to be more common secondary to peritoneal dialysis [7].

The pathogenesis of this disease is unknown and poorly understood. Hsu et al. [8] categorized it in two groups: peritoneal dialysis-dependent and peritoneal dialysis-independent intra-abdominal cocoon. Peritoneal dialysis-dependent is probably related to the duration of peritoneal dialysis, repetitive infection, acidity of the solution, high osmolarity and sterilizing agent such as chlorhexidine. Peritoneal dialysis-independent factors include beta blockers and genetic predisposition or developmental in the form of omental dysplasia [3].

The treatment of intra-abdominal cocoon is adhesolysis and excision of the fibrotic membrane. The procedure should be done adequately in order to decrease the recurrence of small bowel obstruction. Most of the cases described were managed with a laparotomy incision, however others were successfully treated with minimally invasive surgery [9]. 
To prevent extensive adhesion, which may lead to the recurrence of small bowel obstruction in $12 \%$, it is suggested to rinse the peritoneal cavity with an abherent such as sodium hyaluronate or hydrocortisone and to relieve postoperative ileus with early ambulation and mosapride administration.

\section{Conclusion}

Abdominal cocoon is a rare disease. We present a case with intra-cocoon bleeding following a motor vehicle accident. The publication of this article aims at raising the awareness of this disease and possibly the increased incidence of mesenteric tear after blunt abdominal wall trauma in patients with this disease. Treatment is still surgical exploration even if the patient's condition is stable to prevent extensive adhesion formation from the intra-cocoon blood and thus decrease the incidence of small bowel obstruction which presents commonly in this disease.

\section{Disclosure Statement}

The authors received no financial support. 


\begin{tabular}{r|l|l|l}
$\begin{aligned} \text { Case Reports in } \\
\text { Gastroenterology }\end{aligned}$ & $\begin{array}{l}\text { Case Rep Gastroenterol 2011;5:206-211 } \\
\text { DOl: 10.1159/000326946 }\end{array}$ & $\begin{array}{l}\text { Published online: } \\
\text { April 13, 2011 }\end{array}$ & $\begin{array}{l}\text { O 2011 S. Karger AG, Basel } \\
\text { ISSN 1662-0631 } \\
\text { www.karger.com/crg }\end{array}$ \\
\hline
\end{tabular}


Fig. 1. Contrast-enhanced axial computerized tomography sections at the mid abdomen showing loculated hematoma (b, arrow) limited by a well-defined sheath-forming sac containing the small bowel loops (a, arrow). 


\begin{tabular}{l|l|l|l}
$\begin{array}{c}\text { Case Reports in } \\
\text { Gastroenterology }\end{array}$ & $\begin{array}{l}\text { Case Rep Gastroenterol 2011;5:206-211 } \\
\text { DOI: 10.1159/000326946 }\end{array}$ & $\begin{array}{l}\text { Published online: } \\
\text { April 13, 2011 }\end{array}$ & $\begin{array}{l}\text { O 2011 S. Karger AG, Basel } \\
\text { ISSN 1662-0631 } \\
\text { www.karger.com/crg }\end{array}$ \\
\hline
\end{tabular}
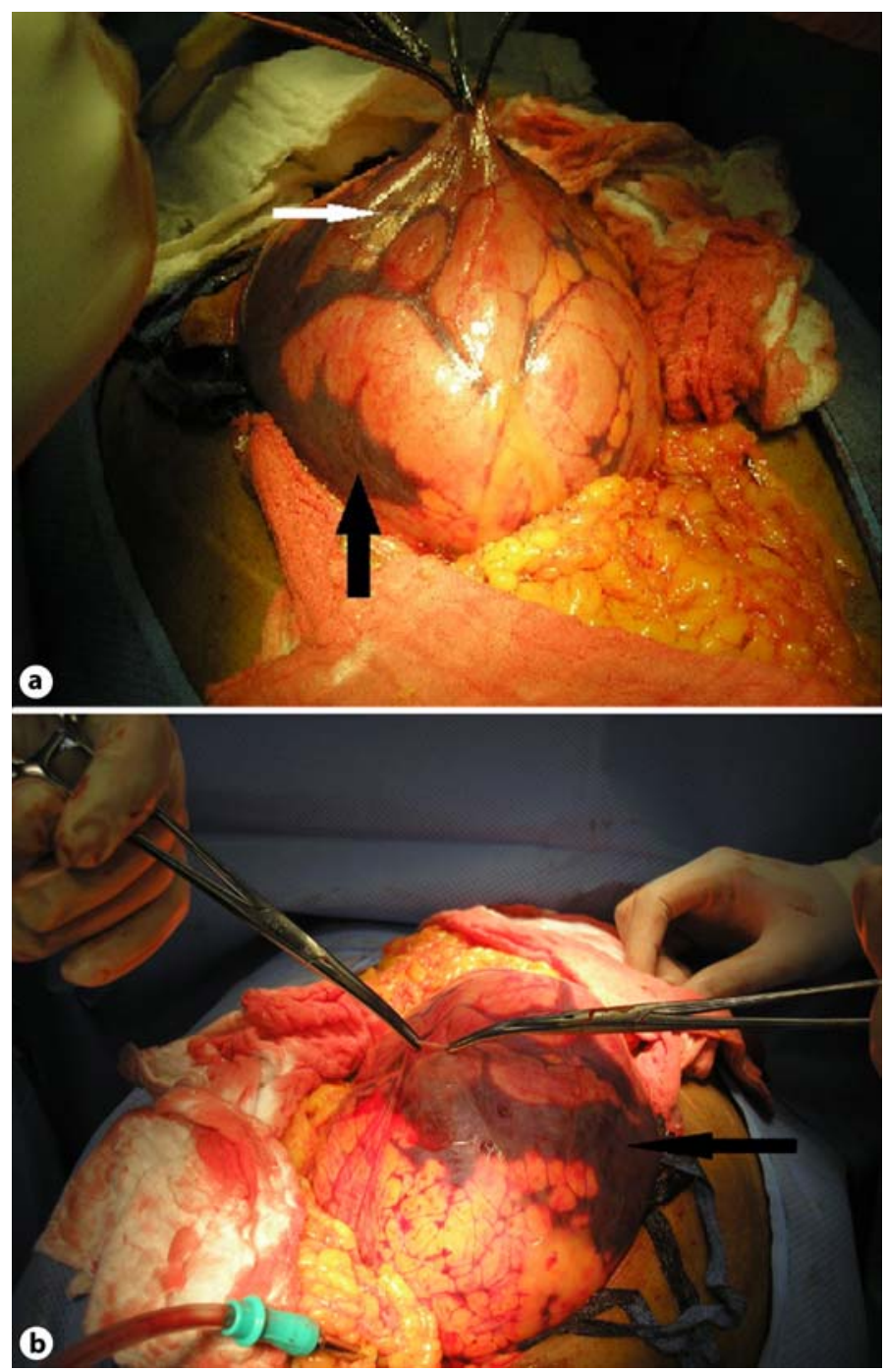

Fig. 2. Abdominal cocoon encasing the small intestine (black arrows) with intra-cocoon blood (white arrow) as shown in both pictures. 


\begin{tabular}{c|l|l|l}
$\begin{aligned} \text { Case Reports in } \\
\text { Gastroenterology }\end{aligned}$ & $\begin{array}{l}\text { Case Rep Gastroenterol 2011;5:206-211 } \\
\text { DOl: 10.1159/000326946 }\end{array}$ & $\begin{array}{l}\text { Published online: } \\
\text { April 13, 2011 }\end{array}$ & $\begin{array}{l}\text { O 2011 S. Karger AG, Basel } \\
\text { ISSN 1662-0631 } \\
\text { www.karger.com/crg }\end{array}$ \\
\hline
\end{tabular}

\section{References}

1 Owtschinnikow PJ: Peritonitis chronica fibrosa incapsulata. Arch Klin Chir 1907;83:623-634.

-2 Foo KT, Ng KC, Rauff A, et al: Unusual small intestinal obstruction in adolescent girls: the abdominal cocoon. Br J Surg 1978;65:427-430.

3 Wei B, Wei HB, Guo WP, Zheng ZH, Huang Y, Hu BG, Huang JL: Diagnosis and treatment of abdominal cocoon: a report of 24 cases. Am J Surg 2009;198:348-353.

4 Sieck JO, Cowgill R, Larkworthy W: Peritoneal encapsulation and abdominal cocoon: case reports and review of literature. Gastroenterology 1983;84:1597-1601.

5 Maguire D, Srininvasan P, O'Grady J, Rela M, Heaton ND: Sclerosing encapsulating peritonitis after orthotopic liver transplantation. Am J Surg 2001;182:151-154.

6 Wig JD, Gupta SK: Computed tomography in abdominal cocoon. J Clin Gastroenterol 1998;26:156-157.

7 Clatworthy MR, Williams P, Watson CJ, Jamieson NV: The calcified abdominal cocoon. Lancet 2008;371:1452.

$\checkmark 8$ Hsu YH, Hsia CC, Tsai DM, Tu HY, Hung KY, Huang JW: Development of encapsulating peritoneal sclerosis following bacterial peritonitis in a peritoneal dialysis patient. Am J Kidney Dis 2010;55:198-202.

\$ Makam R, Chamany T, Ramesh S, Potluri VK, Varadaraju PJ, Kasabe P: Laparoscopic management of abdominal cocoon. J Minim Access Surg 2008;4:15-17. 